\title{
Did Biology Emerge from Biotite in Micaceous Clay?
}

\author{
H. Greenwood Hansma ${ }^{*}$ \\ Physics Department, University of California, Santa Barbara, CA; hhansma@physics.ucsb.edu \\ 1 Physics Department, University of California, Santa Barbara, CA; hhansma@physics.ucsb.edu \\ * Correspondence: hhansma@physics.ucsb.edu
}

Received: date; Accepted: date; Published: date

\begin{abstract}
An origin of life between the sheets of micaceous clay is proposed to involve the following steps: 1) evolution of metabolic cycles and nucleic acid replication, in separate niches in biotite mica; 2) evolution of protein synthesis on ribosomes formed by liquid-in-liquid phase separation; 3) repeated encapsulation by membranes of molecules required for the metabolic cycles, replication, and protein synthesis; 4) interactions and fusion of the these membranes containing enclosed molecules; resulting eventually in 5) an occasional living cell, containing everything necessary for life. The spaces between mica sheets have many strengths as a site for life's origins: mechanochemistry and wet-dry cycles as energy sources, an 0.5-nm anionic crystal lattice with potassium counterions $\left(\mathrm{K}^{+}\right)$, hydrogen-bonding, enclosure, and more. Mica pieces in micaceous clay are large enough to support mechanochemistry from moving mica sheets. Biotite mica is an ironrich mica capable of redox reactions, where the stages of life's origins could have occurred, in micaceous clay.
\end{abstract}

Keywords: clay; mica; biotite; muscovite; origin of life; origins of life; mechanical energy; work; wetdry cycles

\section{Introduction}

Somewhere there was a habitat, hospitable for everything needed for the origins of life. This is an essential requirement for life's origins. In this habitat, there were places where metabolic cycles were evolving. There were places where replication and protein synthesis on ribosomes were evolving. Maybe this habitat was the black mica, biotite (Fig. 1). Maybe there were places between some biotite sheets where metabolic cycles were forming and places between other biotite sheets where replication was coming into being. Membranes were forming and were encapsulating the molecules that were accumulating between the biotite sheets. Membrane-enclosed protocells tended to aggregate, bringing together the molecules for metabolic cycles, replication, and protein synthesis. After a long long time, occasionally a membrane would encapsulate everything needed for a living cell (Fig. 2). 


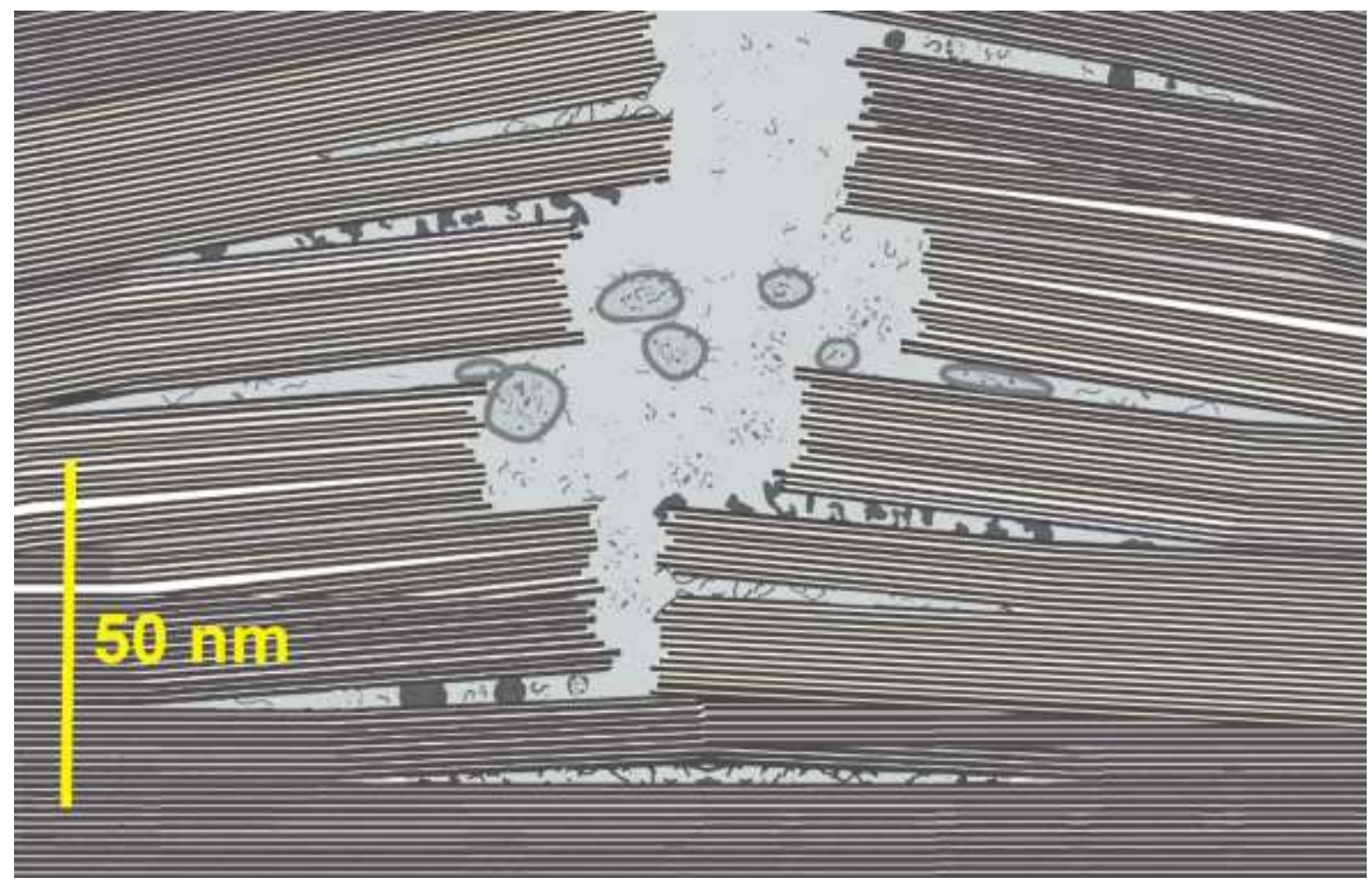

Figure 1. Nanometer-scale diagram of how life might have originated between biotite mica sheets. Niches within the biotite sheets provide compartments for molecular evolution of different processes essential for life.

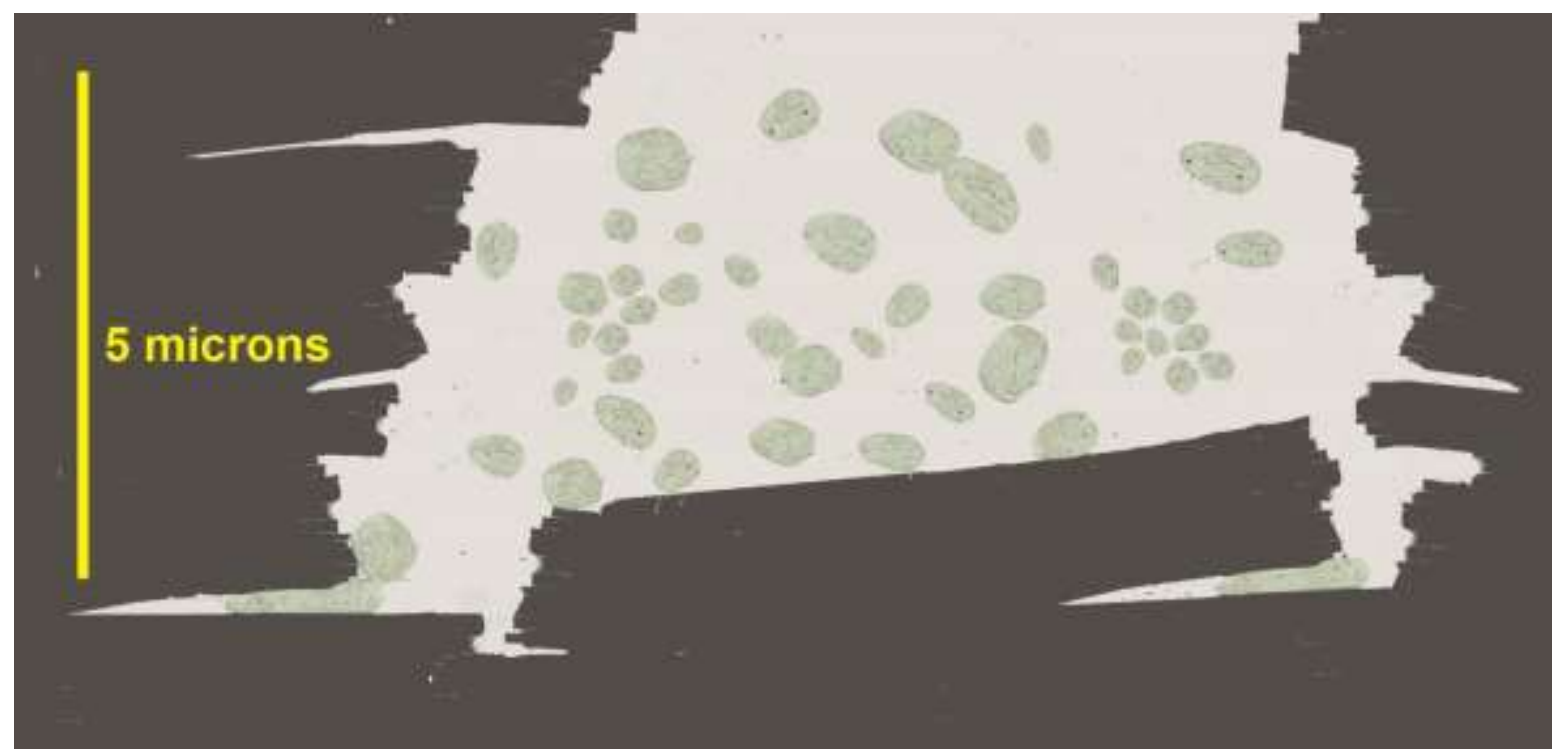

Figure 2. Micron-scale diagram of how life might have originated between biotite mica sheets. Protocells in the aqueous environment can encapsulate prebiotic molecules in the niches between mica sheets. Mechanical energy from moving mica sheets can bleb off protocells, as seen in the lower left corner of the figure. Eventually, occasionally, a living cell will be produced.

\section{Why micas?}

The spaces between the sheets in mica 'books' could have been the ancient cellular compartments that sheltered and concentrated the earliest biomolecules, before membrane-bound cells emerged (Fig. 1) [1-6]. These cellular compartments have an anionic crystal lattice, with 'ceilings' and 'floors' forming tiny solid-state synthesis chambers. The mineral sheets of biotite and muscovite 
micas have a layered silicate structure, like montmorillonite and illite clays, which have been used successfully to catalyze reactions non-enzymatially, such as the synthesis of biopolymers. [7-10].

Micas are non-swelling minerals, unlike clays such as montmorillonite, which swells and shrinks during wet-dry cycles. Water seeps slowly in and out at the edges of mica sheets, providing a more stable wet-dry environment for life's origins than clay. Experimentally, water seeped a few millimeters between the sheets of mica pieces that were cycled daily between $22^{\circ} \mathrm{C}$ and $4^{\circ} \mathrm{C}$ for 2 weeks [2].

Another advantage of micas is that their sheets are bridged by potassium ions $\left(\mathrm{K}^{+}\right)$, which are found in all living cells. This makes biotite and muscovite micas attractive minerals for life's origins, by providing the source of the $\mathrm{K}^{+}$for living systems. Mica particles are also much larger than clay particles, which are $\sim 1-2$ microns in size.

The slow wet-dry cycles that occur between mica sheets are good for forming biopolymers without hydrolyzing them too fast. Slow drying between mica sheets is shown in Fig. 6 of Hansma [2]. In contrast, rapid wet-dry cycles in clay cause polymerization to be followed more quickly by depolymerization [11]. This 'water problem' of rapid wet-dry cycles makes it difficult to form polymers at the origins of life [12] [13].

Mica sheets move, open and shut, at their edges and are thus in the constant state of nonequilibrium that is needed for life.

\subsection{Mechanical Energy from Moving Mica Sheets}

In addition to the entropic energy from wet-dry cycles [14], moving mica sheets provide another endless energy source for the origins of life (Fig. 3) [6]. This is mechanical energy, which can be used for mechanochemistry. Mechanochemistry is a growing research field, in which biomolecules are synthesized with mechanical forces [15].

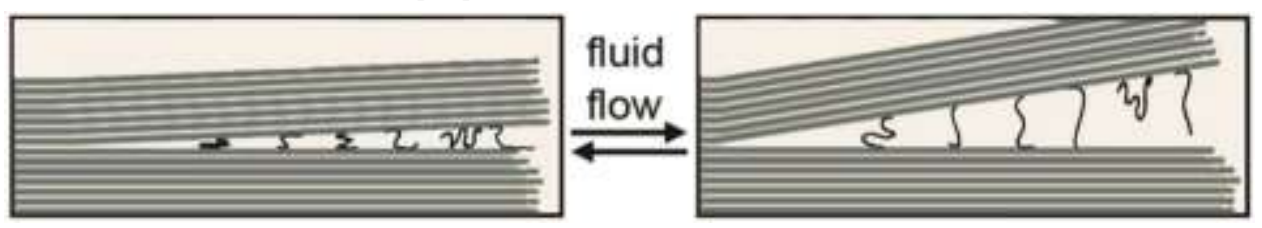

Figure 3. Diagram of moving mica sheets used to produce mechanical energy.

This mechanical energy can be used to synthesize prebiotic molecules, stretch and compress polymers, or bleb off protocells. [2]. Seven mica sheets, as shown in this diagram, provides enough force to form a covalent bond when moved a distance of $0.1 \mathrm{~nm}$.

How much energy can moving mica sheets provide? If the mica sheets move even 0.1 nanometer $(\mathrm{nm})$ closer together, they can push together 2 molecules to form a covalent bond, if the mica has a spring constant stiff enough to provide 170 piconewtons $(\mathrm{pN})$ of force [2]. The equation for a spring constant, $\mathrm{F}=\mathrm{kx}$, with $\mathrm{x}=0.1 \mathrm{~nm}$, shows that a spring constant $(\mathrm{k})$ of $1.7 \mathrm{~N} / \mathrm{m}$ (Newtons/meter) is stiff enough. The spring constant of the mica depends on the number of mica sheets in the layer that is moving open and shut. Each mica sheet is $\sim 1 \mathrm{~nm}$ thick. Only about 7 mica sheets are needed to provide this spring constant, as shown in Fig. 4 of [16]. This is in air. Even in water, mica would provide an energy source with more than enough energy for an origin of life between mica sheets.

\subsection{How big do the mica sheets need to be?}

One needs only tiny pieces of mica to for mechanochemistry. The mica fragments in micaceous clays are large enough to have sheltered emerging life. The 'mica world' diagrams in Fig. 2 are lengthened, in Fig. 4, to show that even nanoscale mica fragments are big enough to produce sufficient mechanical energy for life's emergence. Therefore, life may have emerged in micaceous clay, which is widely present on Earth. 


\section{micaceous clay}

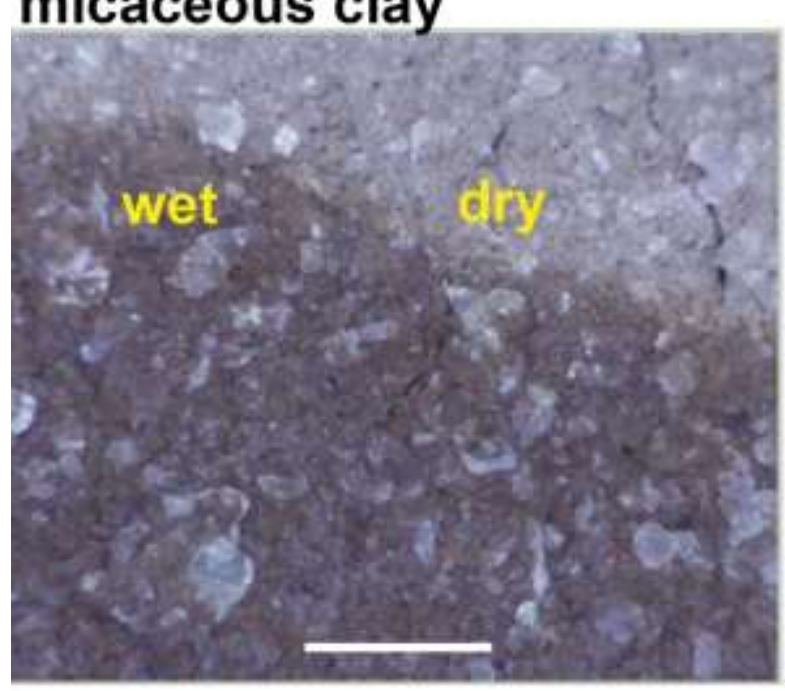

\section{mica from micaceous clay}

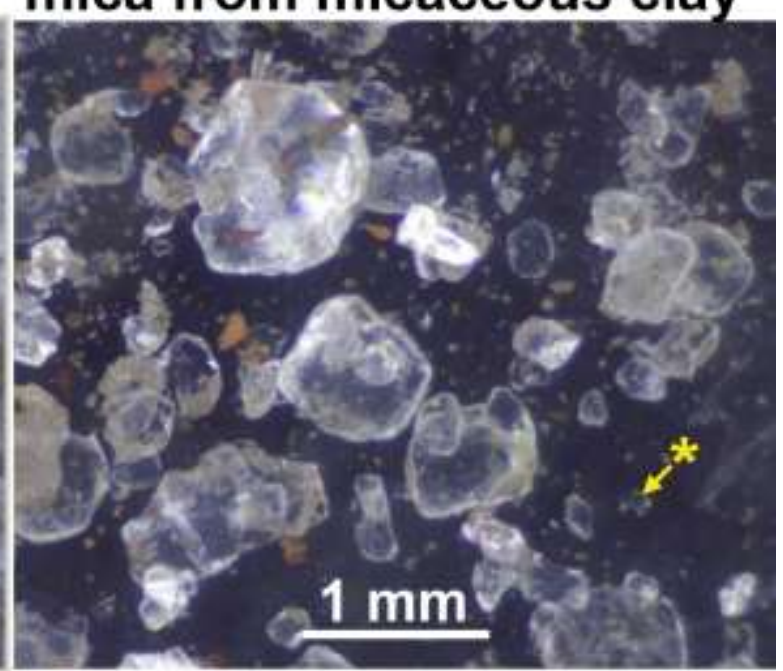

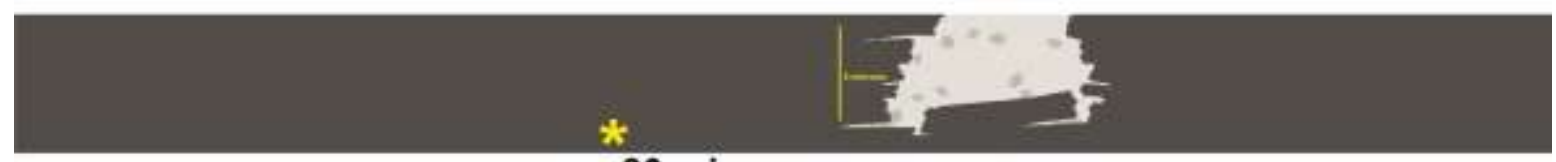

80 microns

Figure 4. Micaceous clay and life's origins. Top Left: a brown micaceous clay ("New Mexico Clay") containing pale reflecting pieces of mica, in the middle of a wet-dry cycle. Top Right: mica and a few clay particles, washed from the micaceous clay. Yellow asterisk and arrow point to a mica fragment with a diameter of 80 microns. Scale bars are $1 \mathrm{~mm}$. Bottom: mica diagram, showing the length of 80 microns, relative to the sizes of protocells and mica structures of Fig. 2.

\subsection{Why is biotite a better mica?}

Biotite mica has advantages over muscovite mica. Biotite, and black mica, are common names used for a subgroup of generally dark-colored, iron-bearing micas, including the species annite, tetraferriannite, ferroceladonite, fluorannite. Biotite is rich in iron (Fe) and magnesium (Mg) (Fig. 5). The iron is predominately $\mathrm{Fe}(\mathrm{II})$, capable of reducing organic molecules, as needed for life's emergence [17]. Especially in the Hadean reducing environment, Fe(II) predominated over Fe(III). $\mathrm{Mg}(\mathrm{II})$ is also a useful cation, being a major inorganic divalent cation in living systems.

Biotite is the most conductive mica, because its iron $(\mathrm{Fe})$ conducts electrons. The electric current increases exponentially with the iron content of the micas. [18, 19]. Acid accelerates the dissolution of biotite, acting primarily at step edges of biotite sheets and etch pits [20]. Biotite is also found on Mars, which may have been the original source of life in the solar system, seeding life on earth [21]. 


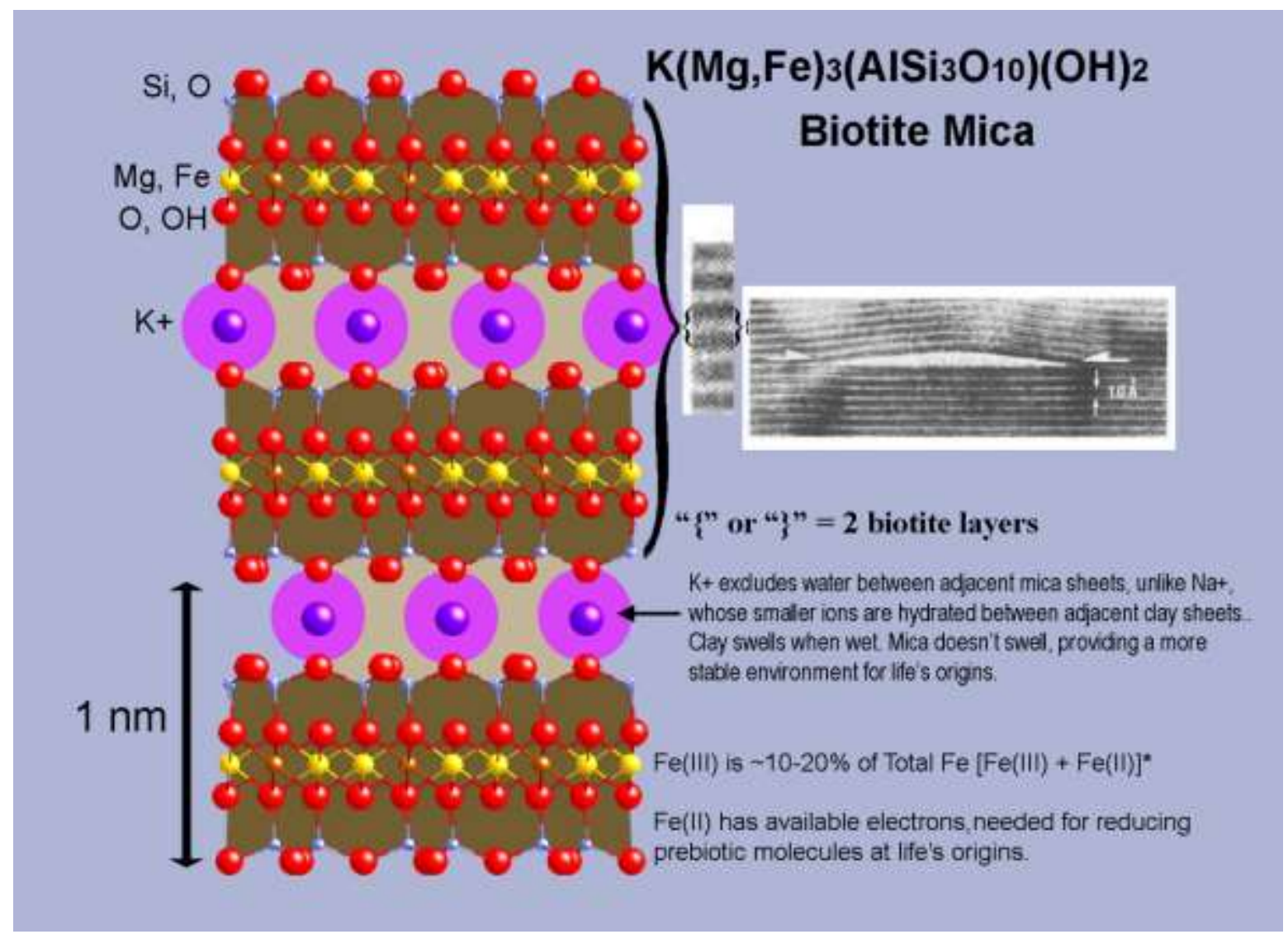

Figure 5. Biotite mineral structure (CrystalMaker image) with HRTEM image of biotite bubble [22] and data (Fe(III) is $\sim 10-20 \%$ of total Fe) from [17].

\section{Clay}

Clay has long been considered as a site for life's origins, and clay surfaces catalyze or support polymerizations of amino acids and nucleotides. Because clays swell and shrink during wet-dry cycles, clays provide only unstable environments for the origins of life. Micas do not swell and shrink like clays. Micas would provide stable environments for most or all of the various origin-of-life worlds, including RNA worlds [23-25], RNA-peptide worlds [26-28], lipid worlds [29-31], metabolism first [32,33], hydrothermal vents [34] (mica has been used for windows in wood stoves), and others [35].

Many clays are too young to have been present at life's origins, $\sim 4$ billion years ago. Many clays may contain traces of the earliest life, but they are not the oldest clays, which have been destroyed by tectonic activity in the last 3 billion years and more. Muscovite and biotite are among the major minerals found in zircon grains from the Hadean [36]. Clays form in association with the water needed for life [37], which is another advantage of clay over other rocks and minerals.

As Hazen says, even traces of a mineral could have been sufficient for the mineral to be involved in life's origins [38]. Borates, for example, were not present in large quantities at life's origins [39]. Borates, however, are valuable for stabilizing ribose; even traces of borate on the early earth might have served this function [40,41].

Dyson says error tolerance is essential for life's origins [42]. With the redundancy of the vast areas between biotite mica sheets, in micaceous clay, almost everything can go wrong, and life will still emerge.

\section{Biology and Mica}

\subsection{Membranes and the Origins of Life}


Membranes are stable on mica, as observed by Atomic Force Microscopy [43-45]. Vesicles on mica fuse to form bilayers and multilayers. However, mica sheets would have provided the 'cells' or compartments for emerging life, without the need for membranes. Membranes are fragile. They leak, acquire and lose molecules, swell, and rupture.

Membranes were not essential when life was emerging. At this time, 3 essential components were: 1) metabolic processes, 2) the replication of information, and 3) protein synthesis on ribosomes. There is an increasingly popular alternative to membranes at the origins of life - 'membraneless organelles'. Peptides/proteins and RNA interact in 'membraneless organelles' or 'membraneless biomolecular condensates' in living cells, as nucleoli and other particles [46-48]. These particles form by liquid-in-liquid phase separation [49].

Ribosomes are ancient biomolecular condensates, composed of proteins and RNA, and are necessary for translating nucleic acids into proteins. Ribosomes were present in the Last Universal Common Ancestor of life (LUCA) [50]. When life was coming into being, in the pre-LUCA stages, ribosomes and their precursors may have been early 'membraneless organelles', protected within mica sheets [5, 51-55]. Prokaryotic ribosomes are $\sim 20 \mathrm{~nm}$ in diameter, larger than the largest vesicle in Fig. 1.

"The evolution of ... membranes would ... be [a] late development" say Root-Bernstein et al. in their paper about 'prebiotic ecology [56]. An 'ecosystems first' perspective is proposed by Baum and others, based on their intriguing research involving chemical selection on mineral surfaces [57]. "If even one enzyme were missing, all metabolic processes would cease," according to a skeptic about abiogenesis [58].

Perhaps, instead of membranes, protolife evolved as an acellular ecosystem, sharing all the necessary enzymes in an open system. Imagine pieces of this ecosystem periodically encapsulating in membranes. Nearly all of these membrane-encapsulated protocells would lack some essential component of life or enzyme. Occasionally a membrane-encapsulated protocell would contain all the essential components of life and became alive. Occasionally one of these living protocells would reproduce and begin seeding Earth with Life.

\subsection{DNA on Mica}

Mica's anionic crystal surface is good for the reversible binding of nucleic acids such as DNA. This can be done by using different exchangeable cations to adjust the binding strength of DNA and other anionic polymers to mica. For example, freshly cleaved mica was soaked in $33 \mathrm{mM}$ magnesium acetate to bind DNA to mica for early imaging by Atomic Force Microscopy in air [59] (Fig. 6). $\mathrm{Ni}^{++}$, $\mathrm{Co}^{++}$, and $\mathrm{Zn}^{++}$salts were used for stable imaging of DNA in aqueous fluid; in contrast, DNA binding was not strong enough for AFM imaging when salts of $\mathrm{Mn}^{++}, \mathrm{Cd}^{++}, \mathrm{Hg}^{++}$, or $\mathrm{K}^{+}$were used [60].

Nucleotide monophosphates of Adenine (A), Guanine (G), Cytosine (C) and Uracil (U) on mica were cycled through wet-dry cycles at $80^{\circ} \mathrm{C}$ and imaged by AFM [61]. This simple process, with no enzymes or activated nucleotides, produced RNA on bare mica. RNA lengths were $100-1000$ nucleotides, which is about an order of magnitude longer than the RNA lengths obtained when polymerization occurred in the presence of lipids [31]. It makes sense that mica's anionic crystal lattice was better for polymerizing RNA, which has the same periodicity $-0.5 \mathrm{~nm}$ - as mica. Mica may have been a template for RNA polymerization at life's origins. Perhaps nucleic acid linkages are $3^{\prime}-5^{\prime}$ and not $2^{\prime}-5^{\prime}$ because mica sheets served as a template that favored $3^{\prime}-5^{\prime}$ linkages. Perhaps nucleotide templating on mica prevented diphosphate linkages, which form a bent polymer. 


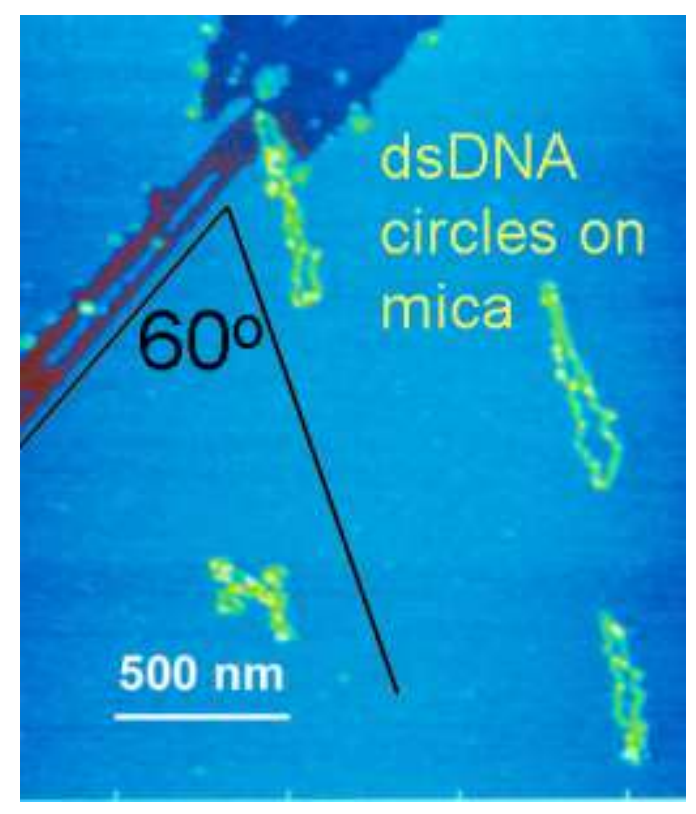

Figure 6. Figure 6. Atomic Force Microscopy of double-stranded DNA circles on mica with a crack. Three of the 4 dsDNA circles form a 60-degree angle with the mica crack, consistent with alignment on mica's hexagonal crystal lattice.

\subsection{Sugars}

Sugars, especially ribose, are a major biomolecule in living systems. A plausible prebiotic reaction for forming sugars is the formose reaction, in which formaldehyde reacts to form sugars [62]. In a test tube, the end products become increasingly large polymers of sugars, branched sugar polymers, and eventually a tarry mess. In the confined spaces between mica sheets, simpler sugars are likely to predominate. Mica's anionic hexagonal lattice may also favor linear oligosaccharides over branched or bent ones.

\section{Mica and Life}

Mica sheets have similarities with life, as would be expected for a place where life might have originated (Table 1) [2, 3]. Mica sheets and nucleic acid polymers are anionic, with exchangeable inorganic cations. The anionic sites on the surfaces of mica sheets have a periodicity of $0.5 \mathrm{~nm}$, which is also the spacing of phosphate groups in single-stranded nucleic acids. Hydrogen bonds (H-bonds) form in vast numbers in living systems. H-bonds also form between organic molecules and the mica surface [63]. Both mica sheets and enzymes have open and shut motions that do work on the molecules between them. As the title of a recent article says, 'Enzymes at work are enzymes in motion' [64]. 


\begin{tabular}{|c|c|}
\hline Life & Mica \\
\hline Cellular & Stacks of thin mineral sheets separate 'cellular' spaces \\
\hline High in Potassium ions & Potassium ions bridge mica sheets \\
\hline$\left[\mathrm{K}^{+}\right]_{\text {cytoplasm }} \sim 100 \mathrm{mM}$ & {$\left[\mathrm{K}^{+}\right] \sim 100 \mathrm{mM}$ for mica sheets $\sim 0.7 \mathrm{~nm}$ apart } \\
\hline Nucleotides polymerize to DNA \& RNA & Nucleotides polymerize to RNA in wet/dry cycles* \\
\hline $\begin{array}{c}0.5 \mathrm{~nm} \text { spacing of anionic phosphates in ssDNA \& sugars in } \\
\text { carbohydrates** }\end{array}$ & $0.5 \mathrm{~nm}$ anionic crystal lattice on mica surface \\
\hline $\begin{array}{c}\text { Exchangeable inorganic cations bridge anionic sites on } \\
\text { molecules such as DNA }\end{array}$ & $\begin{array}{c}\text { Exchangeable inorganic cations bridge anionic sites } \\
\text { between mica sheets }\end{array}$ \\
\hline Low in entropy & Low in entropy \\
\hline Water-rich & Hydrophilic \\
\hline Forms H-bonds & Forms H-bonds \\
\hline Mechanical energy of enzyme motion & Mechanical energy from moving mica sheets \\
\hline Synthesis of biomolecules in confined spaces $\&$ on surfaces & $\begin{array}{l}\text { Supports chemistry of confinement \& solid phase } \\
\text { synthesis }\end{array}$ \\
\hline Filled and covered with lipid membranes & Supports lipid membranes \& vesicles \\
\hline Eats \& excretes & $\begin{array}{l}\text { Fluid flow between mica sheets carries molecules in } \\
\text { and out }\end{array}$ \\
\hline
\end{tabular}

Table 1. Ways in which Life Imitates Mica.

\section{Dielectric constant at surfaces}

The Dielectric constant, or permissivity, of water is 80 for bulk water but only $\sim 2$ for the first 2 or 3 water layers above a surface (ca. $2 \mathrm{~nm}$ ). $[65,66]$ This means that the charges on charged molecules will become progressively unscreened as the charged molecules approach the mica surface. Electrostatic forces will be strong, pulling cations and cationic molecules to the mica surface and forming bridges between mica and anionic organic molecules.

\section{Crowding}

"There is a growing consensus that confinement may have facilitated the transformation of inanimate matter into living organisms" [67].

Molecules in cells are crowded. The space between protein molecules in cells is typically only $10 \mathrm{~nm}$ [68]. Crowding speeds up the rates of reactions that are diffusion limited [69]. Crowding may even be the origin of homochirality [4]. Given the molecular crowding in living cells, molecular crowding at life's origins is a desirable scenario for hypotheses about the origins of life. Molecules in wet-dry cycles become crowded during the drying phase. Molecules in narrow spaces between mica sheets will typically be crowded, by the mica sheets above and below, in addition to crowding by other molecules.

Confinement chemistry would occur between mica's sheets and during wet-dry cycles and during the compression stage of mechanochemistry. Chemistry in confined spaces produces fewer different molecules and simpler molecules [70, 71]. Confined spaces also help proteins fold [72, 73].

\section{Conclusions}

The Experimental Method traditionally starts with a hypothesis, followed by experimentally testing the hypothesis. Research on the origins of life is not so simple. Because the origins of life are largely a historical science, much is hypothetical, both experiments and ideas [74]. Experimental results show what is possible today. Experimental results give us ideas about how life might have originated, but they cannot prove how life originated.

Biology may have emerged from the spaces between biotite sheets in micaceous clay. We will probably never know for certain whether this is true or not.

Funding: This research received no external funding.

Acknowledgments: Thank you to my brother James Hays Greenwood for raising the question of biotite for the origins of life, to Simon Crase for suggesting tiny pieces of mica, to Katherine Lieban for writing guidance, to 
Anna Wang for her inspiring talk on Building Protocell Communities at AAM2020, the Australasian Astrobiology Meeting, and to Bob Hazen for helpful suggestions.

Conflicts of Interest: The author declares no conflict of interest.

\section{References:}

1. Hansma, H.G., Could Life Originate between Mica Sheets?: Mechanochemical Biomolecular Synthesis and the Origins of Life, in Probing Mechanics at Nanoscale Dimensions, N. Tamura, et al., Editors. 2009, Materials Research Society: Warrendale, PA. p. II03-15.

2. Hansma, H.G., Possible origin of life between mica sheets. Journal of Theoretical Biology, 2010. 266(1): p. 175188.

3. Hansma, H.G., Possible Origin of Life between Mica Sheets: How Life Imitates Mica. J. Biol. Struct. Dynamics, 2013. 31(8): p. 888-895.

4. Hansma, H.G., The Power of Crowding for the Origins of Life. Origins of Life and Evolution of Biospheres, 2014. 44(4): p. 307-311.

5. Hansma, H.G., Better than Membranes at the Origin of Life? Life, 2017. 7(2): p. 28.

6. Hansma, H.G., Mechanical Energy before Chemical Energy at the Origins of Life? Sci, 2020. 2: p. 19.

7. Ferris, J.P., et al., Synthesis of long prebiotic oligomers on mineral surfaces. Nature, 1996. 381: p. 59-61.

8. Ferris, J.P. and G. Ertem, Montmorillonite catalysis of RNA oligomer formation in aqueous solution. A model for the prebiotic formation of RNA. Journal of the American Chemical Society, 1993. 115(26): p. 12270-12275.

9. Joshi, P.C., et al., Mechanism of Montmorillonite Catalysis in the Formation of RNA Oligomers. Journal of the American Chemical Society, 2009. 131(37): p. 13369-13374.

10. Pir Cakmak, F. and C.D. Keating, Combining Catalytic Microparticles with Droplets Formed by Phase Coexistence: Adsorption and Activity of Natural Clays at the Aqueous/Aqueous Interface. Scientific Reports, 2017. 7(1): p. 3215.

11. Lahav, N., D. White, and S. Chang, Peptide formation in the prebiotic era: thermal condensation of glycine in fluctuating clay environments. Science, 1978. 201(4350): p. 67-69.

12. Cafferty, B.J. and N.V. Hud, Abiotic synthesis of RNA in water: a common goal of prebiotic chemistry and bottomup synthetic biology. Current opinion in chemical biology, 2014. 22: p. 146-157.

13. Grover, M.A., et al., A chemical engineering perspective on the origins of life. Processes, 2015. 3(2): p. 309-338.

14. Ross, D. and D. Deamer, Prebiotic Oligomer Assembly: What Was the Energy Source? Astrobiology, 2019. 19(4): p. 517-521.

15. Wang, G.-W., Mechanochemical organic synthesis. Chemical Society Reviews, 2013. 42(18): p. 7668-7700.

16. Castellanos-Gomez, A., et al., Mechanical properties of freely suspended atomically thin dielectric layers of mica. Nano Research, 2012. 5(8): p. 550-557.

17. Shane, P., V. Smith, and I. Nairn, Biotite composition as a tool for the identification of Quaternary tephra beds. Quaternary Research, 2003. 59(2): p. 262-270.

18. Crine, J., et al., The relationship between chemical composition and electrical conductivity of some North American micas. Canadian Journal of Physics, 1977. 55(3): p. 270-275.

19. Meunier, M., et al., Electrical conduction in biotite micas. Journal of applied physics, 1983. 54(2): p. 898-905.

20. Li, J., et al., Effects of citrate on the dissolution and transformation of biotite, analyzed by chemical and atomic force microscopy. Applied geochemistry, 2014. 51: p. 101-108.

21. Bridges, J.C. and P.H. Warren, The SNC meteorites: basaltic igneous processes on Mars. Journal of the Geological Society, 2006. 163: p. 229-251.

22. Banos, J.O., et al., Interlayering and interlayer slip in biotite as seen by HRTEM. American Mineralogist, 1983. 68(7-8): p. 754-758.

23. Joyce, G.F. and L.E. Orgel, Progress toward Understanding the Origin of the RNA World, in The RNA World: the nature of modern RNA suggests a prebiotic RNA, R.F. Gesteland, T.R. Cech, and J.F. Atkins, Editors. 2006, Cold Spring Harbor Laboratory Press: Cold Spring Harbor, New York. p. 23-56.

24. Cech, T.R., Crawling out of the RNA world. Cell, 2009. 136(4): p. 599-602.

25. Gilbert, W., The RNA World. Nature, 1986. 319: p. 618.

26. Van der Gulik, P.T. and D. Speijer, How amino acids and peptides shaped the RNA world. Life, 2015. 5(1): p. 230246.

27. Kaddour, H. and N. Sahai, Synergism and mutualism in non-enzymatic RNA polymerization. Life, 2014. 4(4): p. 598-620.

28. Chatterjee, S. and S. Yadav, The origin of prebiotic information system in the peptide/RNA world: a simulation model of the evolution of translation and the genetic code. Life, 2019. 9(1): p. 25. 
29. Damer, B., et al. An Origin of Life through Three Coupled Phases in Cycling Hydrothermal Pools with Distribution and Adaptive Radiation to Marine Stromatolites. in Proceedings of the 2016 Gordon Research Conference on the Origins of Life. 2016.

30. Lancet, D., D. Segrè, and A. Kahana, Twenty Years of "Lipid World": A Fertile Partnership with David Deamer. Life, 2019. 9(4): p. 77.

31. Rajamani, S., et al., Lipid-assisted Synthesis of RNA-like Polymers from Mononucleotides. Origins of Life and Evolution of Biospheres, 2008. 38(1): p. 57-74.

32. Goldman, A.D., J.A. Baross, and R. Samudrala, The enzymatic and metabolic capabilities of early life. PLoS One, 2012. 7(9).

33. Xavier, J.C., et al., Autocatalytic chemical networks at the origin of metabolism. Proceedings of the Royal Society B, 2020. 287(1922): p. 20192377.

34. Russell, M.J., The importance of being alkaline. Science, 2003. 302(5645): p. 580-581.

35. Saladino, R., et al., Genetics first or metabolism first? The formamide clue. Chemical Society Reviews, 2012. 41(16): p. 5526-5565.

36. Papineau, D., Mineral environments on the earliest Earth. Elements, 2010. 6(1): p. 25-30.

37. Westall, F., Life on the early Earth: a sedimentary view. Science, 2005. 308(5720): p. 366-367.

38. Morrison, S.M., S.E. Runyon, and R.M. Hazen, The Paleomineralogy of the Hadean Eon Revisited. Life, 2018. 8(4): p. 64.

39. Hazen, R.M., et al., Mineral Evolution. American Mineralogist, 2008. 93: p. 1693-1720

40. Benner, S.A., A. Ricardo, and M.A. Carrigan, Is there a common chemical model for life in the universe? Current Opinion in Chemical Biology, 2004. 8(672-689).

41. Benner, S.A., Prebiotic plausibility and networks of paradox-resolving independent models. Nature communications, 2018. 9(1): p. 1-3.

42. Dyson, F.J., Origins of life. Rev. ed. 1999, Cambridge [England] ; New York: Cambridge University Press. ix, $100 \mathrm{p}$.

43. Dufrêne, Y.F. and G.U. Lee, Advances in the characterization of supported lipid films with the atomic force microscope. Biochimica et Biophysica Acta (BBA)-Biomembranes, 2000. 1509(1-2): p. 14-41.

44. Hansma, H.G. and J. Hoh, Biomolecular imaging with the atomic force microscope. Annual Review of Biophysics and Biomolecular Structure, 1994. 23: p. 115-139.

45. Weisenhorn, A.L., et al., Molecular-Resolution Images of Langmuir-Blodgett Films and DNA by Atomic Force Microscopy. Langmuir, 1991. 7: p. 8-12.

46. Hyman, A.A., C.A. Weber, and F. Jülicher, Liquid-liquid phase separation in biology. Annual review of cell and developmental biology, 2014. 30: p. 39-58.

47. Marko, J.F., The liquid drop nature of nucleoli. Nucleus, 2012. 3(2): p. 115-117.

48. Weber, S.C. and C.P. Brangwynne, Getting RNA and protein in phase. Cell, 2012. 149(6): p. 1188-1191.

49. Brangwynne, C.P., Phase transitions and size scaling of membrane-less organelles. The Journal of cell biology, 2013. 203(6): p. 875-881.

50. Hsiao, C., et al., Peeling the onion: ribosomes are ancient molecular fossils. Molecular Biology and Evolution, 2009. 26(11): p. 2415-2425.

51. Cakmak, F.P. and C.D. Keating, Combining catalytic microparticles with droplets formed by phase coexistence: Adsorption and activity of natural clays at the aqueous/aqueous interface. Scientific reports, 2017. 7(1): p. 1-14.

52. Tena-Solsona, M., et al., Self-selection of dissipative assemblies driven by primitive chemical reaction networks. Nature communications, 2018. 9(1): p. 1-8.

53. Poudyal, R.R., et al., Template-directed RNA polymerization and enhanced ribozyme catalysis inside membraneless compartments formed by coacervates. Nature communications, 2019. 10(1): p. 1-13.

54. Drobot, B., et al., Compartmentalised RNA catalysis in membrane-free coacervate protocells. Nature communications, 2018. 9(1): p. 1-9.

55. Jia, T.Z., et al., Membraneless polyester microdroplets as primordial compartments at the origins of life. Proceedings of the National Academy of Sciences, 2019. 116(32): p. 15830-15835.

56. Hunding, A., et al., Compositional complementarity and prebiotic ecology in the origin of life. Bioessays, 2006. 28(4): p. 399-412.

57. Vincent, L., et al., Chemical Ecosystem Selection on Mineral Surfaces Reveals Long-Term Dynamics Consistent with the Spontaneous Emergence of Mutual Catalysis. Life, 2019. 9(4): p. 80.

58. Miller, B. and J. England. Hot Wired. Inference: International Review of Science 2020.

59. Hansma, H.G., et al., Atomic force microscopy of single- and double-stranded DNA. Nucleic Acids Res, 1992. 20(14): p. 3585-90. 
60. Hansma, H.G. and D.E. Laney, DNA binding to mica correlates with cationic radius: assay by atomic force microscopy. Biophys. J., 1996. 70: p. 1933-1939.

61. Hassenkam, T., et al., Viroid-sized rings self-assemble from mononucleotides through wet-dry cycling: implications for the origin of life. bioRxiv, 2020.

62. Lambert, J.B., S.A. Gurusamy-Thangavelu, and K. Ma, The silicate-mediated formose reaction: bottom-up synthesis of sugar silicates. Science, 2010. 327(5968): p. 984-6.

63. Yu, J., et al., Adaptive hydrophobic and hydrophilic interactions of mussel foot proteins with organic thin films. Proceedings of the National Academy of Sciences, 2013. 110(39): p. 15680-15685.

64. Saleh, T. and C.G. Kalodimos, Enzymes at work are enzymes in motion. Science, 2017. 355(6322): p. $247-248$.

65. Fumagalli, L., et al., Anomalously low dielectric constant of confined water. Science, 2018. 360(6395): p. 13391342.

66. Kalinin, S.V., Feel the dielectric force. Science, 2018. 360(6395): p. 1302-1302.

67. Grommet, A.B., M. Feller, and R. Klajn, Chemical reactivity under nanoconfinement. Nature Nanotechnology, 2020: p. 1-16.

68. Phillips, R., J. Kondev, and J. Theriot, Physical biology of the cell. 2008, New York: Garland Science.

69. Ross, D.S. and D. Deamer, Dry/wet cycling and the thermodynamics and kinetics of prebiotic polymer synthesis. Life, 2016. 6(3): p. 28.

70. Sozzani, P., et al., Complete shape retention in the transformation of silica to polymer micro-objects. Nature materials, 2006. 5(7): p. 545-551.

71. Sozzani, P., et al., Traveling Defects in 1,4-trans-Polybutadiene as an Inclusion Complex in Perhydrotriphenylene Canals and a Comparison with Molecular Motions in the Crystalline Solid State. Macromolecules, 1989. 22: p. 3318-3322.

72. Thirumalai, D., D.K. Klimov, and G.H. Lorimer, Caging helps proteins fold. Proc Natl Acad Sci U S A, 2003. 100(20): p. 11195-7.

73. Klimov, D.K. and D. Thirumalai, Dissecting the assembly of Abeta16-22 amyloid peptides into antiparallel beta sheets. Structure, 2003. 11(3): p. 295-307.

74. Pross, A. and R. Pascal, The origin of life: what we know, what we can know and what we will never know. Open biology, 2013. 3(3): p. 120190. 